\title{
Seasonal Variation in the Physicochemical Characteristics and Microalgae of Selected Mangrove Ecosystems in Ernakulam
}

\author{
${ }^{1}$ Aquiline Ans. K, ${ }^{2}$ Dr. Romilly Margaret Mendez \\ ${ }^{1}$ Department of botany, St. Teresa's college, Ernakulam, Cochin-682035. \\ ${ }^{2}$ Associate professor, Department of botany, St. Teresa's college, Ernakulam, Cochin-682035.
}

\begin{abstract}
The present study was carried out to determine the physicochemical characteristics of water and the diversity of microalgae in three different mangrove ecosystems of Ernakulam district for a period of one year. Surface water temperatures varied from $30^{\circ} \mathrm{C}$ to $32^{\circ} \mathrm{C}$. The $\mathrm{pH}$ ranged from 7.1 to 8.4 at all the stations during the course of study. The variation in the dissolved oxygen ranged from 0.48 to $1.28 \mathrm{mg} / \mathrm{l}$, carbon dioxide from 0.88 to $3.6 \mathrm{ppm}$, alkalinity ranged from 15 to $20 \mathrm{ppm}$ and the dissolved chloride ions ranges from $7.28 \mathrm{~g} / \mathrm{l}$ to $8.07 \mathrm{~g} / \mathrm{l}$. Concentrations of nutrients viz. phosphate (10.3 to $93.6 \mu \mathrm{g} / \mathrm{l}$ ), nitrate (28.6 to $110.6 \mu \mathrm{g} / \mathrm{l})$, varied independently their concentration recorded its maximum during the post monsoon period at all the stations studied. The presence of 18 different genera from Cyanophyceae, Chlorophyceae and Bacillariophyceae was recorded in the three stations. Oscillatoria, Chlorella and Navicula were the dominant species at all the three stations investigated.
\end{abstract}

Keywords: Mangroves, Microlgae, physicochemical parameters, and wetland ecosystem.

\section{Introduction}

Phytoplankton blooms are prominent features of biological variability in shallow coastal ecosystem [1]. Mangrove algae produce substantial proportion of biomass, which contributes to the coastal ecosystems. Mangrove ecosystem acts as a buffer between near shore and lagoon or estuarine environments with regard to the influence of freshwater discharge and salinity regime [2]. The study of mangrove regions is necessary as they are highly productive and play an important role as breeding and nursery grounds for many commercially important fishes especially shrimps [3].

Relatively less is known for the seasonal variation in the occurrence and biomass of mangrove associated algae [4]. Sediment and water characteristics, including nutrient levels, are assessed in order to examine all variables that may be influencing algal distribution and abundance [5]. The spatial distribution and diversity of macrobenthos and their relationships between physicochemical parameters of the water and sediment in different mangrove habitats of Tamil Nadu, India during different seasons of the year-2011 [6]. The distribution pattern of macro algae in Pichavaram mangroves (South India)was carried out[7]. The distinctive seasonal and zonal variation in the species diversity, biomass, and element accumulation capacities of macroalgae in two major intertidal mangrove stand types (Avicennia marina assemblage and Sonneratia apetala assemblage) in the Zhanjiang region of southern China [8].

\section{Materials And Methods}

Surface water samples were collected from three stations fixed around the Cochin back water mangroves ecosystem. Station1 (Kumbalangi), station 2 (Puthuype), station 3 (Vallarpadam) for a period of one year from February 2009 to January 2010. Duplicate samples were analysed for hydrological parameters. Water temperature was measured at the station itself. Details of $\mathrm{pH}$, salinity, D.O was made according to [9]. Inorganic phosphate and nitrate was estimated using the method of [10]. The phytoplankton group was studied for 1 litre from counts in $50 \mathrm{ml}$ samples obtained after the organism settled in special chambers for $24 \mathrm{hrs}$. An average of three were recorded. The distribution of algae on the mangrove ecosystem was studied by collecting water samples. The algae growing on the barks and pneumatophores were also scrapped off with the help of a forceps and were observed.

\section{Results And Discussion}

The hydrographic parameters in the estuary was found to vary with the climate and the influx of fresh water during the monsoon. The period of interpretation was pre monsoon (from the month of February to May) monsoon (June to September) and Post monsoon (October to January In the present study, temperature showed less fluctuation in different stations. The surface temperature ranged from 26.0 (lowest) to 31.9 (highest). The highest temperature was recorded in pre-monsoon (31.9) at station II. The lowest temperature was recorded in monsoon (26.0) at station II (Fig. 3.1). A narrow range of fluctuations in physico chemical characteristics was observed not only during the different months studied but also in between different stations. Temperature 
showed diurnal and seasonal variations [11]. In the study on the benthic Bacillariophyta of the Paripe river estuary in Brazil the temperature was found to be constant throughout the year and the $\mathrm{pH}$ was always alkaline[12]. In the present study the $\mathrm{pH}$ value ranged from 6.4 (lowest) to 7.9 (highest). The lowest $\mathrm{pH}$ of 6.4 was recorded from station III during monsoon period. The highest $\mathrm{pH}$ of 7.9 was recorded from site 3 during pre-monsoon (Fig. 3.2). The fluctuations observed in all physicochemical parameters may be attributed to the variations in the agro climatic prevailing followed by the oscillatory difference of tidal amplitude, a phenomena which is expected in the tide influenced wet land ecosystem [13].

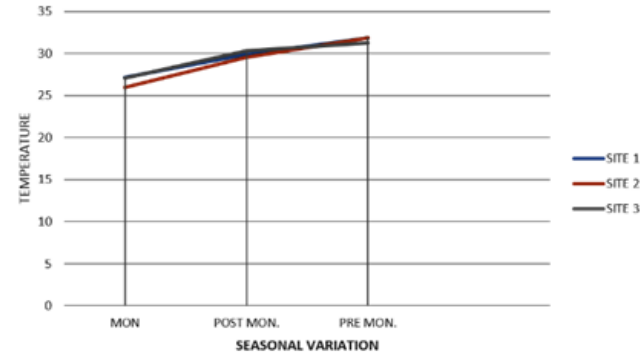

Fig 3.1: Seasonal mean distribution in temperature at the stations

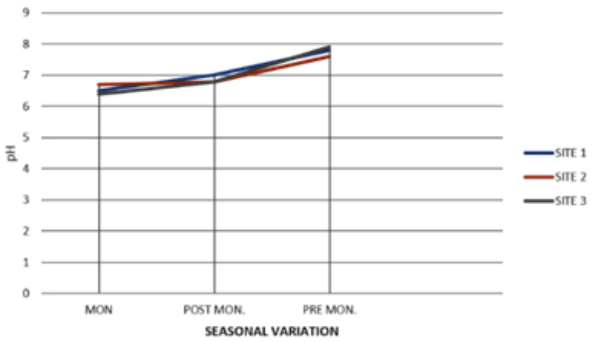

Fig 3.2: Seasonal mean distribution in $\mathrm{pH}$ at the stations

In the present study, the total alkalinity was found to be same as that of bicarbonate alkalinity. In this present work, Chloride concentration was high, and it ranges from 9.2 to 14.5. Lowest value reported during monsoon. The highest dissolved chloride ions value was recorded in pre monsoon from station I1.The lowest dissolved chloride ions value was recorded in monsoon from station III (Fig. 3.3). High chloride value in fresh waters was due to domestic wastes and decomposition of natural debris[18]. High chloride concentration obtained during this study might be due to natural debris.

Alkalinity of the water is its capacity to neutralize a strong acid and is characterized by the presence of all hydroxyl ions capable of combining with the hydrogen ion. In the present work the carbonate alkalinity was found to be 0 . Bicarbonate alkalinity ranged from 15 to 18 . The lowest value was reported during monsoon from station I \& II. The highest Alkalinity was recorded in pre monsoon from station II (Fig. 3.4).

In this present work, it was found that the amount of dissolved oxygen was less in the mangrove estuaries especially during pre-monsoon. In a study on the interstitial waters and histochemistry of mangrove forests and adjoining water system of South West coast India dissolved oxygen was reported to be low in mangrove waters [14]. The Dissolved oxygen value ranged from 1.0 (lowest) to 3.7 (highest). The highest Dissolved oxygen value was recorded in monsoon and post monsoon (3.7) from station II \& I. The lowest Dissolved oxygen value was recorded in pre monsoon (1.0) from station I (Fig. 3.5). In the present investigation, higher values of dissolved oxygen were recorded during monsoon months at all the stations. Relatively lower values were found during summer, which could be mainly due to reduced agitation in the coastal and estuarine waters. Higher dissolved oxygen concentration observed during the monsoon season might be due to the cumulative effect of higher wind velocity coupled with heavy rainfall and the resultant freshwater mixing. [15] and [16] mainly attributed seasonal variation of dissolved oxygen to freshwater influx and ferruginous impact of sediments.

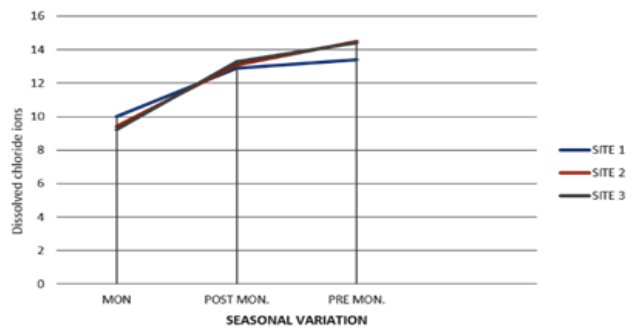

Fig 3.3: Seasonal mean distribution in dissolved chloride ions at the stations

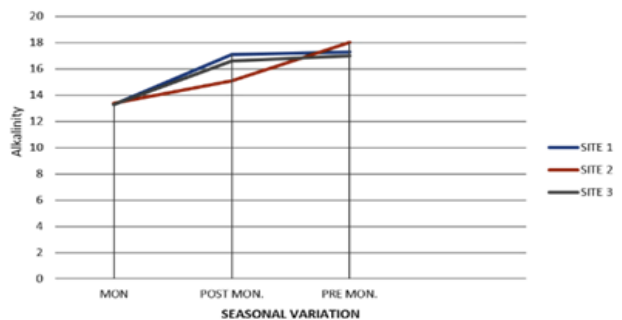

Fig 3.4: Seasonal mean distribution in alkalinity at the stations

Carbon dioxide show irregular fluctuations. It ranges from 1.3 to 2.7 . It was very low during premonsoon from site I. The highest Carbon dioxide value was recorded in pre monsoon (2.7) from station II (Fig 3.6). Irregular fluctuations observed in the carbon dioxide may result from the breakdown of organic matter. [17] 


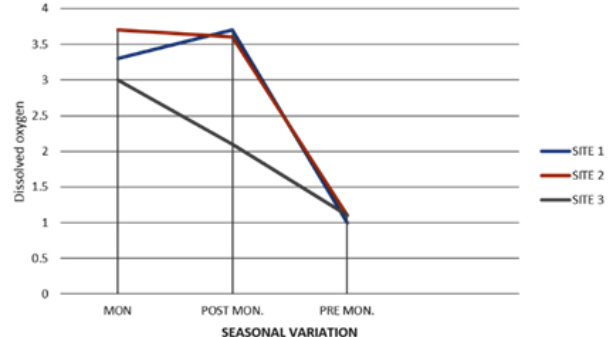

Fig 3.5: Seasonal mean distribution in DO at the stations

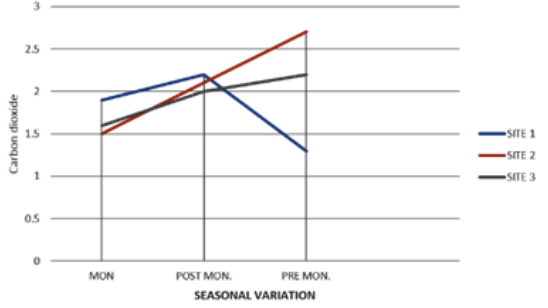

Fig 3.6: Seasonal mean distribution in dissolved Carbon dioxide at the stations

Nutrients are considered as one of the most important parameters in the mangrove environment influencing growth, reproduction and metabolic activities of biotic components. Distribution of nutrients is mainly based on season, tidal conditions and freshwater flow from land [18]. In the present study, the inorganic phosphate ranged from 10.3 to $93.6 \mu \mathrm{g} / 1$ in all the three stations (Fig. 3.7). High concentration of inorganic phosphate observed during the post monsoon season $(93.6 \mu \mathrm{g}$ 1-1at station 3 during December). This might be possibly due to intrusion of upwelling seawater into the creek, which increased the level of phosphate [19]. Further, regeneration and release of total phosphorus from bottom mud into the water column by turbulence and mixing also contributed to the higher values during monsoon [20]. High concentration of nitrates observed during the post monsoon season of January (110.6 $\mu \mathrm{g}$ 1-1at station III). Nitrates recorded its lowest value of $28.6 \mu \mathrm{g} / 1$ at station 1 in June (Fig. 3.8). In general nutrients recorded the highest values in the postmonsoon period. In the present study, influx of nutrients from the bottom appears to be the reason for increase in nutrient levels during the post monsoon period. The possible way of nitrate input would be through oxidation of ammonia a form of nitrogen to nitrite and consequently to nitrite [21]. The recorded low values during nonmonsoonal period may be due to its utilizations by phytoplankton as evidenced by high photosynthetic activity and also due to the dominance of marine water intrusion with negligible amount of nitrate [22].

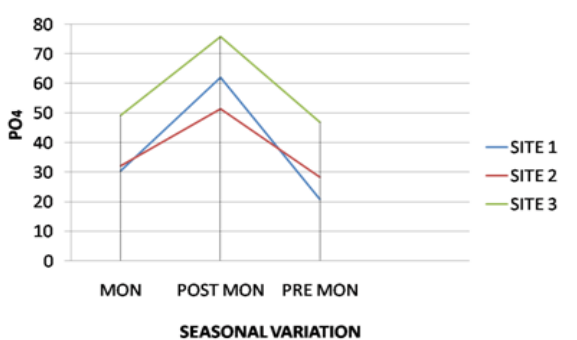

Fig 3.7: Monthly variation in $\mathrm{PO}_{4}$ in the station studied

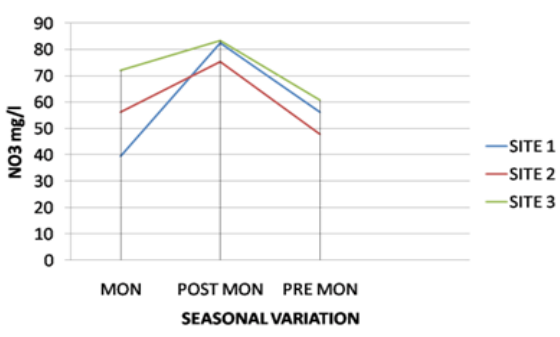

Fig 3.8: Monthly variation in $\mathrm{NO}_{4}$ in the station studied

The algae identified in this present study were belonging to Bacillariophyceae, Cyanophyceae, Chlorophyceae. (Table.3.1). The algae found predominantly in the post monsoon were Spirulina labyrinthiformis, Oscillatoria formosa, Melosira lumuloides, Rhoicosphenia, Amphora laevis, Cymbella hustedfii, Navicula mutica, Gyrosigme belticum, Pleurosigma aestuari, Nitzschia closterium, Cyclotella striata, Pleurosigma angulatum and Thalassiosira subtilis The algae found predominantly in the pre monsoon were Biddulphia mobilensis, Rhoicosphenia, Pleurosigma aestuarii, Thalassiosira subtilis, and Pleurosigma sp. The results of [23] indicated that intertidal position within sites have the greatest influence on algal frequency the abundance and distribution patterns of algal communities were likely to be influenced by seasonal variation, wave action, sediment, nutrients and other chemical-physical parameters and habitat conditions. The algae found predominantly in the monsoon in all the stations investigated included Chlorella vulgaris, Cosmarium guadrum Biddulphia mobilensis, Rhoicosphenia, Cymbella hustedfii, Navicula mutica, Pleurosigma aestuari, Nitzschia closterium, Cyclotella striata and Pleurosigma sp. Rhoicosphenia, Pleurosigma aestuarii and Nitzschia closterium, were found in all the stations during the course of study during all seasons.

In the study of the biodiversity and its conservation in the Sunderban mangrove ecosystem majority of the algae belonging to the class Bacillariophyceae and Chlorophyceae was reported[24]. These algae are capable of fixing $\mathrm{N}_{2}$ in the soil, can with stand desiccation and are adapted to live under wide range by $\mathrm{pH}$. They identified the algae belonging to the class Bacillariophyceae, Cyanophyceae, Chlorophyceae and Euglinophyceae. Blue Green Algae like Oscillatoria, Spirulina, Phormidium, Lyngbya, and Anabaena was identified in this present study. [25] conducted a study on distribution and abundance of the mangrove vegetation and mangrove algae at 
Vypeen under varying hydrobiological condition. The study revealed that the mangrove rhizosphere algae were mainly composed of Blue Green Algae. The main reason for this may be eutropication and warmer climate. [26] identified several species of green, blue green algae and seaweeds enter in the mangrove water. It includes species of Scenedesmus, Oocystis, Chlorella, Ulothrix, Cladophora, Oedogonium, Spirulina, Anabaena, Nostoc, Oscillatoria and Lyngbya. In the present study Rhoicosphenia, Pleurosigma aestuarii and Nitzschia closterium, were found in all the stations during the course of study during all seasons. The highest diversity of Pleurosigma normanii was recorded during monsoon at all the stations studied. The abundance and distribution patterns of algal communities were likely to be influenced by seasonal variation, wave action, sediment, nutrients and other chemical-physical parameters and habitat conditions. The variation in their responses to ambient concentrations of different nutrients, implying their differential ability to absorb and selectively accumulate certain elements[27].

\section{Conclusion}

The present work pertains to the microalgae of the selected mangroves of Ernakulam district. Due to tidal influence and mixing of fresh and marine water in the mangrove ecosystem several species of green, blue green algae and seaweeds enter into mangrove waters. The diatoms are found to occur in the water as well as attached to the decaying leaves and pneumatophores of the mangrove plants. The wet land ecosystem and mangroves are very productive. The information obtained from the above study highlights the importance of preservation of wetland ecosystem and its preservation for human sustainence.

TABLE 4.1 Seasonal mean distribution of microalgae $\left(\right.$ Cellsx $\left.10^{2} / \mathrm{L}^{-1}\right)$

\begin{tabular}{|c|c|c|c|c|c|c|c|c|c|}
\hline \multirow[t]{2}{*}{ ALGAE } & \multicolumn{3}{|c|}{ station 1} & \multicolumn{3}{|c|}{ station 2} & \multicolumn{3}{|c|}{ station 3} \\
\hline & Pre & Mon & Post & Pre & Mon & Post & Pre & Mon & Post \\
\hline $\begin{array}{l}\text { Cyanophyceae } \\
\text { Spirulina labyrinthiformis }\end{array}$ & - & 26.3 & 78.7 & - & 32.3 & 80.5 & 71.5 & - & 38.3 \\
\hline Oscillatoria formosa & - & 42.4 & 34.8 & - & 12.9 & 96.2 & 14.4 . & - & 67.2 \\
\hline $\begin{array}{l}\text { Chlorophyceae } \\
\text { Ulothrix zonata } \\
\end{array}$ & - & - & - & - & - & - & - & 32.4 & - \\
\hline Oedogonium patulum & 12.3 & - & - & - & 28.6 & - & - & - & - \\
\hline Chlorella vulgaris & - & 39.7 & - & 12.6 & 18.3 & 12.5 & - & 872 & - \\
\hline Cosmarium quadrum & - & 62.6 & - & - & 23.4 & - & - & 26.3 & - \\
\hline $\begin{array}{l}\text { Bacillariophyceae } \\
\text { Biddulphia mobilensis }\end{array}$ & 26.4 & 42.5 & - & 16.4 & 43.4 & 7.4 & 17.4 & 29.6 & - \\
\hline Melosira lumuloides & - & - & 14.5 & - & - & 18 & - & - & 24 \\
\hline Rhoicosphenia abbreviata & 93.9 & 12.3 & 87 & 82 & 14 & 71 & 62 & 16 & 71 \\
\hline Amphora laevis & - & - & 32.7 & - & - & 13.8 & - & - & 49.6 \\
\hline Cymbella cistula & - & 36.4 & 8 & - & 49.5 & 16.6 & 36 & 62 & 14.2 \\
\hline Navicula mutica & 59.4 & 12.7 & 38 & 86.3 & 20 & 72.8 & - & 14.5 & 71.8 \\
\hline Gyrosigma belticum & - & - & 42.3 & - & 71.6 & 43 & 108 & 45 & 28.3 \\
\hline Pleurosigma aestuarii & 79.6 & 30.5 & 86.3 & 102.5 & 26.7 & 78.8 & 64.1 & 42.2 & 117 \\
\hline Nitzschia closterium & 82.3 & 26.9 & 93.7 & 64 & 30 & 98 & - & 18.6 & 78.8 \\
\hline Cyclotella striata & - & 36.1 & 46.4 & - & 18.3 & 116 & - & 32.4 & 47.6 \\
\hline Skeletonema costatum & 16.2 & - & - & 12.8 & 48.5 & - & - & 53 & - \\
\hline Thalassiosira subtilis & 72.5 & - & 38.4 & 42.3 .4 & - & 76.3 & 71.2 & - & 86.8 \\
\hline Certium hirudinella & - & - & 20.5 & - & - & - & - & - & 24.4 \\
\hline Gyrosigma balticum & - & - & 14.4 & - & - & 28.9 & - & - & - \\
\hline Pleurosigma angulatum & - & - & 24.3 & - & - & 36.5 & - & - & 28.2 \\
\hline Ceratium furca & 26.2 & 11.4 & - & - & 14.3 & - & - & - & - \\
\hline Gyrosigma tenuissimum & - & 72.6 & 89.7 & - & 54.6 .4 & 73.2 & - & - & - \\
\hline Pleurosigma normanii & 69.5 & 124 & - & 73.3 & 145 & - & 65.7 & 142 & - \\
\hline
\end{tabular}

Pre - Premonsoon (February - May)

Mon - Monsoon ( June - September)

Post - Post Monsoon ( October - January)

\section{References}

[1]. E. James Cloern , Phytoplankton bloom dynamics in coastal ecosystems: A review with some general lessons from sustained investigation of San Francisco Bay, California. Reviews of Geophysics, 34 (2), 1996,127-1

[2]. A.L. Ramanathan, Sediment characteristics of the Pichavaram mangrove environment, southeast coast of India. Ind. J. Mar. Sci, 26, 1997, 319- 322.

[3]. K. Kathiresan, and B.L. Bingham, Biology of mangroves and mangrove ecosystems, Adv. Marine Biol., 40, 2001,81-251.

[4]. Abu Hena Mustafa Kamal Mohd Hanafi Bin Idris and Johan Bin Ismail, Seasonal Variation in the Occurrence and Abundance of Mangrove Macroalgae in a Malaysian Estuary Cryptogamie, Algologie , 37(2), 2016 , 109-120.

[5]. F. Melville Alex Pulkownik, D. Margaret Burchett, Zonal and seasonal variation in the distribution and abundance of mangrove macroalgae in the Parramatta River, Australia, Estuarine Coastal and Shelf science, 64(2), 2005, 267- 276.

[6]. J. Thilagavathi, D. Varadharajan, A. Babu, J .Manoharan, S. distribution and diversity of macrobenthos in different mangrove habitats of Tamil Nadu, India Aquac Res Development ,2013, 4:6. 
[7]. T. Nedumaran and P. Perumal, Temporal and Spatial Variations in the Structure of Macroalgal Communities Associated with Mangroves of Pichavaram (South India , Botany Research International , 2(3), 2009, 198-205,

[8]. Yubin Zhang Yuan Li Fei Shi Xingli Sun Guanghui Lin , Seasonal and spatial variation in species diversity, abundance, and element accumulation capacities of macroalgae in mangrove forests of Zhanjiang, China, Acta Oceanologica Sinica, 33, ( 8), 2014,73-82.

[9]. J.D.H. Strickland, and T.R Parsons, A manual for seawater analysis. Bul . Fish. Res. Board Canada, 167, $1972,310$.

[10]. K. Grasshoff, M. Ehrharrot and K.Kremling. Methods for seawater analysis (Second revised edition) Verlag Chemic. Weinheim, $1983,419$.

[11]. P. Kaladaran, A. Nandakumar, K.K. Valsala, and M. Ancy. Physicochemical parameters of water. Mangrove ecosystem a manual for the assessment of biodiversity, 83, 2005,190.

[12]. A. N. Moura, M.C. Olivera, E.C. Nas Cimento, Benthic bacillariophyta of the aripe river estuary in Pernambaco state, Brazil. Brazilian Journal of biology, (3), 2007,76-88.

[13]. Rajkumar, M., P.Perumal, P. V.Ashok, P.Venadesh, T.K. Rajasekar, Phytoplakton diversity in pichavaram mangrove water from South east cost of India. Journal of Environmental biology: (4).2009, 30.

[14]. Bava and Seralathan, Interstitial water and hydrochemistry of a mangrove forest and adjoining water system, south west coast of India, Environmental Geology 38(1), 1999, 47-52.

[15]. J. Das, S.N. Das and R.K. Sahoo, Semidiurnal variation of some physicochemical parameters in the Mahanadi estuary, east coast of India. Indian J. Mar. Sci., 26, 1997, 323-326.

[16]. A. Saravanakumar, J. Sesh Serebiah, G.A. Thivakaran and M. Rajkumar, Benthic macrofaunal assemblage in the arid zone mangroves of gulf of Kuchchh - Gujarat. J. Ocean Univ. China, 6, 2007,33-39 .

[17]. B. Anandaraj, V. Bhagyalakshmi and R. Lakshmi. 1987. Limnology of river Cooum with special reference to sewage and heavy metal pollution. Indian academic Science, 96, 1987,141- 149.

[18]. M.S. Felipe, J.M. Andrads, A. Carlosena, and R. Tauler ,Temporal characterization of river water in urban and semi urbam areas using physicochemical parameters and chemometric methods. Analytica chemical acta 583 (1), 2007,128-137.

[19]. A. Saravanakumar, M. Rajkumar, G.A. Thivakaran and J. Sesh Serebiah, Abundance and seasonal variations of phytoplankton in the creek waters of western mangrove of Kachchh-Gujarat. J. Environ. Biol., 29, 2008, 271-274 .

[20]. N. B. Nair P. K.Abdul Azis, K. Krishna Kumar, K .Dharmaraj and M Arunachalam Ecology of Indian Estuaries: Physico chemical conditions in Kadinamkulam Backwater, south-west coast of India, Indian J. Mar. Sci. 13 ,1984,69-74.

[21]. R.Chandran and K.Ramamoorthi, Hydrobiological studies in the gradient zone of Vellar Estuary 1- Physico-chemical parameters. Mahasagar-Bull. Natn.Inst. Occanogr, 17, 1984, 69-77.

[22]. M. Rajasegar, Physico-chemical characteristics of the Vellar estuary in relation to shrimp farming, J. Environ. Biol, 24, 2003, 95101.

[23]. Gouda Rajashree and R.C.Panigrahy. Seasonal distribution and behaviour of nitrate and phosphate in Rushikulya estuary, East coast of India. Indian J. Mar. Sci., 24, 1995, 233-235.

[24]. J, S Seangkaew, I. Bovonsombut and Y. Peerapornpisa, Species diversity and distribution of mangrove-associated red alga Bostrychia (Rhodomelaceae, Rhodophyta) from southern Thailand. International Journal of Applied Environmental Sciences , 11( 1) ,2016, 55-71.

[25]. B. Gopal, and M. Chauhan. 2006. Biodiversity and its conservation in the Sunderban mangrove ecosystem. Aquatic science 68, 2006, 338 .

[26]. K.P. Suma, and C. M. Joy. 2003. Hydrobiological studies on mangrove flora and associated algae in Vypeen, Kerala. Nature Env. Poll. Tecno. 2(3), 2003, 269-276.

[27]. C.P. Gopinathan, P.K .Jayasurya, M .Kaliamoorthy, and G.Sunilrmal, Micro algae. Mangrove ecosystem a manual for the assessment of biodiversity. 83, 2005, 20-35. 